\title{
A critique of the Cornell Net Carbohydrate and Protein System with emphasis on dairy cattle. 1. The rumen model
}

\author{
The late G. Alderman \\ revised by J. France and E. Kebreab
}

The University of Reading, Department of Agriculture

Earley Gate, Reading RG6 2AT, UK

(Received 11 April 2000; revised version 30 November 2000; accepted 22 January 2001)

\section{ABSTRACT}

The Comell Net Carbohydrate and Protein System (CNCPS) is primarily a nutrient supply model, since it does not model the utilisation of the absorbed nutrients, other than by using the NRC (1988) net encrgy and NRC (1985) available protein systems to calculate the animal's cnergy, protein and amino acid (AA) requirements. The model incorporates details of the motabolism in the rumen not found in other published models of energy and protein requirements, particularly rates of carbohydrate degradation, predicted rumen $\mathrm{pH}$ and numen nitrogen and peptide balance. The model does not predict volatile fatty acid (VFA) proportions or methane production. Microbial growth is assumed to be dependent upon the rate of carbohydrate degradation, whereas other mathematical models of the rumen relate microbial growth to the concentration of nutrients in the rumen, and also require estimates of rumen volume and microbial mass. The microbial yield of structural carbohydrate (SC) bacteria is not limited or altered by the rumen ammonia supply, with the result that stoichiometrically unsound amounts of microbial protein and negative rumen ammonia levels can be predicted. Only estimated peptide supply modifies the growth of non structural carbolydrate (NSC) bacteria. Solid outflow rates adopted are low at higher levels of feeding compared to ARC (1984) and AFRC (1992), with the result that the proportion of OM digested in the rumen is predicted to be higher (c. 0.75) than the mean value 0.65 adopted by ARC (1980). The effects of liquid outflow rate upon the outflow of NPN, AA and soluble proteins, pectins, sugars, organic acids and VFA arc ignored. Only peptides are affected by the liquid outflow rate in the model. The degradation rates for carbolydrate fractions A and B I proposed are very high, exceeding the possible rate of microbial growth so that microbial synthesis does not respond to considerable variations in these high rates. The adopted maximum microbial yiclds of SC and NSC rumen bacteria are lowered by $20 \%$ to allow for the effects of protozoal predation, which has the effect of compensating for the high predicted microbial yields adopted, but the protozoa are not accounted as contributing to the microbial AAN 
output. Starch disappearance in the rumen is not corrected for protozoal ingestion and its re-appearance in the intestine, nor is there is any accounting for the protozoal contribution to fat uptake in the rumen. Predicted TDN values of forages are therefore sensitive mainly to the rate of cell wall degradation selected. Only one dietary parameter, effective neutral detergent fibre (eNDF\%) defines or modifies maximum microbial yield, microbial maintenance, realised microbial yield, and rates of SC and NSC degradation. The consequence is that both energy and protein supply to the cow are affected by the parameter eNDF when values fall below $24.5 \%$ in diet DM.

KEY WORDS: CNPCS, dairy cows, lactation, rumen, metabolism, cnergy, protein, amino acids, supply

\section{GENERAL DESCRIPTION OF THE MODEL}

Most current nutrient requirement systems for dairy cattle (Madsen, 1985; INRA, 1988; NRC, 1988; SCA, 1990; AFRC, 1993; Tamminga et al., 1994) describe protein metabolism in some detail, with the carbohydrate fractions of the diet featuring only as contributors to the overall energy exchanges in the rumen and absorption as $\mathrm{ME}$, and subsequent utilisation as energy, not as defined energy supplying nutrients, VFA, glucose and fat. The need for nutrient requirement systems based on their fate in the animal's body has been recognised for over twenty years, with the rumen modelling efforts of Baldwin et al. (1977) and France et al. (1982), for example. Their models are complex, mechanistic and dynamic, originating at the biochemical level. They feature numerous equations of the Michaelis-Menten type, are written in a computer simulation language such as CSMP or $\mathrm{C}++$, and require to be integrated over time to get results.

The Cornell Net Carbohydrate and Protein System uses a mixed empirical/ mechanistic and non-dynamic model (i.e. not time dependent) to simulate the nutrient supply side of the ruminant animal, using standard spreadsheet software. Four sub-models are used, encompassing a great deal of published information on the characteristics of feeds, ruminant digestion and absorbed nutrients. It predicts steady state microbial fermentation, feed digestion and passage and end product formation. Further development of the model to remedy this situation has already been published (Pitt et al. 1995, 1996). The rumen model in version 3.0 form deals mainly with the adequacy and balance of the dict formulated in relation to the optimal nutrient supply to the rumen bacteria.

\section{Ruminant feed description}

The CNCPS model relies almost entirely (with the exception of starch) upon the Goering and Van Soest (1970) acid and neutral detergent system of feed analysis both for carbohydrate and protein fractions. This means that most cell content 
fractions other than starch (water soluble carbohydrates (WSC), organic acids and pectins) are not estimated separately, but their sum is computed from cell contents (CC) minus determined starch values. Neutral detergent insoluble N (NDIN) and acid detergent insoluble $\mathrm{N}$ (ADIN) are used to predict digestible and indigestible ruminally undegradable protein.

Neutral Detergent Fibre, NDF. By definition, carbohydrate fractions $\mathrm{B} 2$ and $\mathrm{C}$ together make up NDF, of which fraction B2 is titled 'available fiber', which is equivalent to 'digestible cell walls', or DNDF. Suggested ranges for the rates of degradation of the B2 (cell wall) fractions derived from published data using in vitro or in situ methods are given in Tables 4, 5 and 6 of Sniffen et al. (1992).

Non Structural Carbohydrate, NSC. Total carbohydrate is calculated by subtracting crude protein (CP\%), ether extract (EE\%) and ash (TA\%) from 100, and then NDF\% is subtracted to give NSC. NSC comprises sugar, pectins and organic acids (fraction A), and starch (fraction B1). Pectins and organic acids are not assigned a carbohydrate (CHO) fraction symbol, because they are not dealt with as separate fractions, the presumption apparently being that pectins ferment as fast as the sugar in fraction $\mathrm{A}$, which is reasonable. However, pectins are known to yield an acetate dominated VFA pattern, not propionate, as for water soluble carbohydrates (WSC), so this will have to be corrected when attempting to predict VFA patterns as Pitt et al. (1995) have tried to do. Data for pectins are not given in any of the published tables of feed composition, although a method for pectin has been published (Faichney and White, 1983). The amounts of organic acids (mainly lactic acid) present in un-wilted grass silages and low dry matter maize silages can be of the order of $10 \%$ of the dry matter. Although they are either absorbed de novo or rapidly metabolised by rumen bacteria, contributing to the animal's energy supply, they do not contribute significantly to the microbial energy supply, and can be discounted as in AFRC (1992) and INRA (1988). The inclusion of organic acids in the calculated A 1 CHO fraction unjustifiably increases the Al fraction's contribution to microbial protein synthesis from most silage based diets.

Proteins. The CNCPS has five fractions (A, B1, B2, B3 and C) for protein compared to the four fractions of AFRC (1992), which are quickly degradable protein (QDP), slowly degradable protein (SDP), digestible undegradable protein (DUP) and indigestible undegradable protein (IUDP). The CNCPS B2 protein fraction is equivalent to SDP, whilst fraction B3 equates to DUP, and fraction C to $100-(a+b)$ of Ørskov and Mehrez (1977). The QDP fraction of AFRC (1992) requires correction for solid particulate matter, as Lopez et al. (1994), in order to compare it with the two CNCPS fractions, a non-protein nitrogen fraction (A) and true protein fraction (B1), precipitable by tungstic acid. Inasmuch as buffer soluble true protein can be a source of peptides to the NSC bacteria until they are washed out of the rumen by liquid outflow, this additional fraction is justified. The CNCPS assigns fixed rates of degradation $(\% / h)$ to each protein 
fraction, which are independent of which feed they occur in, namely infinity, $200-300 \%, 5-15 \%, 0.10-0.15 \%$ and 0 for fractions A, B1, B2, B3 and C. This contrasts strongly with both the approach of AFRC (1992) and INRA (1988), which rely upon measurements of the degradation rate of SDP feed proteins in aggregate, using in situ or in vitro rumen liquor techniques.

\section{RUMEN MODEL TO PREDICT MICROBIAL GROWTH}

The CNCPS model of rumen fermentation, described by Russell et al. (1992), divides the ruminal microbial ecosystem into two main groups of rumen bacteria, and the protozoa:

1. SC bacteria only ferment Structural Carbohydrates (cell walls, NDF), only use ammonia as their source of $\mathrm{N}$, and do not ferment peptides or amino acids.

2. NSC bacteria ferment Non-Structural Carbohydrates (starch, pectin, sugars) and use ammonia or peptides and amino acids as their $\mathrm{N}$ sources, and can produce ammonia.

3. Protozoa are not considered in terms of their nutrient requirements, but their effects upon microbial protein synthesis are taken into account quantitatively.

\section{Factors controlling microbial growth}

Carbohydrate supply. The CNCPS model assumes first order degradation characteristics [substrate limited, enzyme excess and specific rate constants $(/ \mathrm{h})$ ] for the $\mathrm{CHO}$ fractions, whilst most other rumen models in addition modify carbohydrate degradation according to microbial mass present (Dijkstra and France, 1996). Rates of degradation $\left(\mathrm{Kd}_{4}, \mathrm{Kd}_{5}, \mathrm{Kd}_{6}\right)$ for the $\mathrm{CHO}$ fractions are tabulated (often as ranges varying $x$ 2) in Sniffen et al. (1992), Tables 4, 5 and 6. These 'logical rates' are stated to be based on in vitro or in situ work published earlier by numerous authors. However, the computer model issued (v 3.0 ) has single point values for each degradation rate rather than ranges. The origin of the listed ranges of A (sugar) and $\mathrm{Bl}$ (starch) CHO fraction degradation rates is obscure, although reference is also made to the unreliability of enzymatic studies.

The model can be criticised for its reliance on feed degradation data obtained from in situ or in vitro studies not calibrated against in vivo data, with the result that much faster rates of degradation for some fractions are used in the model than are observed in the rumen. Results from the in vitro rumen liquor gas pressure transducer technique have already confirmed that they may be an order of magnitude too high for some nutrients in the neutral detergent soluble (NDS) fraction (carbohydrate fractions A, B1) of feeds (Schofield and Pell, 1995). 
No effects of microbial mass or $\mathrm{N}$ supply (other than peptide $\mathrm{N}$ ) upon rates of $\mathrm{CHO}$ degradation are specified in the model. The tabulated degradation rates $\mathrm{Kd}_{6}$ for the B2 (cell wall) fraction by the SC fermenting bacteria are modified in the model by rumen $\mathrm{pH}$ predicted from effective NDF as defined by Mertens (1985). The proportion of the $\mathrm{CHO}$ fractions digested whilst in the rumen (RD) are calculated by equation (1), which includes rate of passage (Kp), which is affected by dry matter intake as described later:

$$
\mathrm{RD}=\mathrm{Kd} /(\mathrm{Kd}+\mathrm{Kp})
$$

Microbial yield. Microbial yield (Y) in the rumen is predicted in the CNCPS by the use of the Pirt (1965) double reciprocal equation, which is rewritten as:

$$
\mathrm{Y}(\mathrm{g} \text { microbial DM/g } \mathrm{CHO})=1 /[(\mathrm{KM} / \mathrm{Kd})+(1 / \mathrm{YG})]
$$

where

$\mathrm{KM}$ is the microbial maintenance cost $(0.05$ and $0.15 \mathrm{~g} \mathrm{CHO} / \mathrm{g}$ microbial DM/ $h$ for SC and NSC bacteria),

$\mathrm{Kd}_{4}, \mathrm{Kd}_{5}, \mathrm{Kd}_{6}$ are the rates of degradation (/h) of the A, B1 and B2 CHO fractions,

$\mathrm{YG}$ is the maximum microbial yield in the model initially set at $0.5 \mathrm{~g}$ microbial $\mathrm{DM} / \mathrm{g}$, CHO degraded, but reduced to $0.4 \mathrm{~g} / \mathrm{g}$ after allowing for protozoal predation.

Using the microbial maintenance figures above, this equation becomes either:

or

$$
\mathrm{Y} 1=1 /\left[0.05 / \mathrm{Kd}_{6}+2.5\right] \text {, for SC bacteria }
$$

$$
\mathrm{Y} 2 \text { or } \mathrm{Y} 3=1 /\left[0.15 /\left(\mathrm{Kd}_{5} \text { or } \mathrm{Kd}_{4}\right)+2.5\right] \text {, for NSC bacteria }
$$

which implies that microbial yield increases as $\mathrm{Kd}$ increases as shown in Figure 1.

It should be noted that with values for $\mathrm{Kd}$ greater than $1.0 / \mathrm{h}(100 \% / \mathrm{h}$ in the CNCPS model), little increase in microbial yield is predicted, so that the very high values for $\mathrm{Kd}$ of $100-400 \%$ for the A fraction (sugar) listed in Tables 4, 5 and 6 of Sniffen et al. (1992) give no significant increase in predicted microbial yield above those for much lower (less than $1.0 / \mathrm{h}$ ) rates of degradation. Schofield and Pell (1995), using gas pressure transducers, reported much lower rates of degradation, 0.15 to $0.19 / \mathrm{h}$ for the NDS fraction (CHO fractions A and $\mathrm{Bl}$ ) of forages, than those used in the model.

The yield of NSC bacteria is stated to be increased by a maximum of $18 \%$ if peptide supply is not limiting, based on the work of Russell and Sniffen (1984). However, J. Dijkstra (personal communication) has pointed out that this conclusion was based on microbial yiclds calculated as $\mathrm{g} \mathrm{DM} / \mathrm{g}$ OM not per $\mathrm{g} \mathrm{CHO}$ as in the CNCPS model. If the data are corrected for the trypticase additions (used as a 


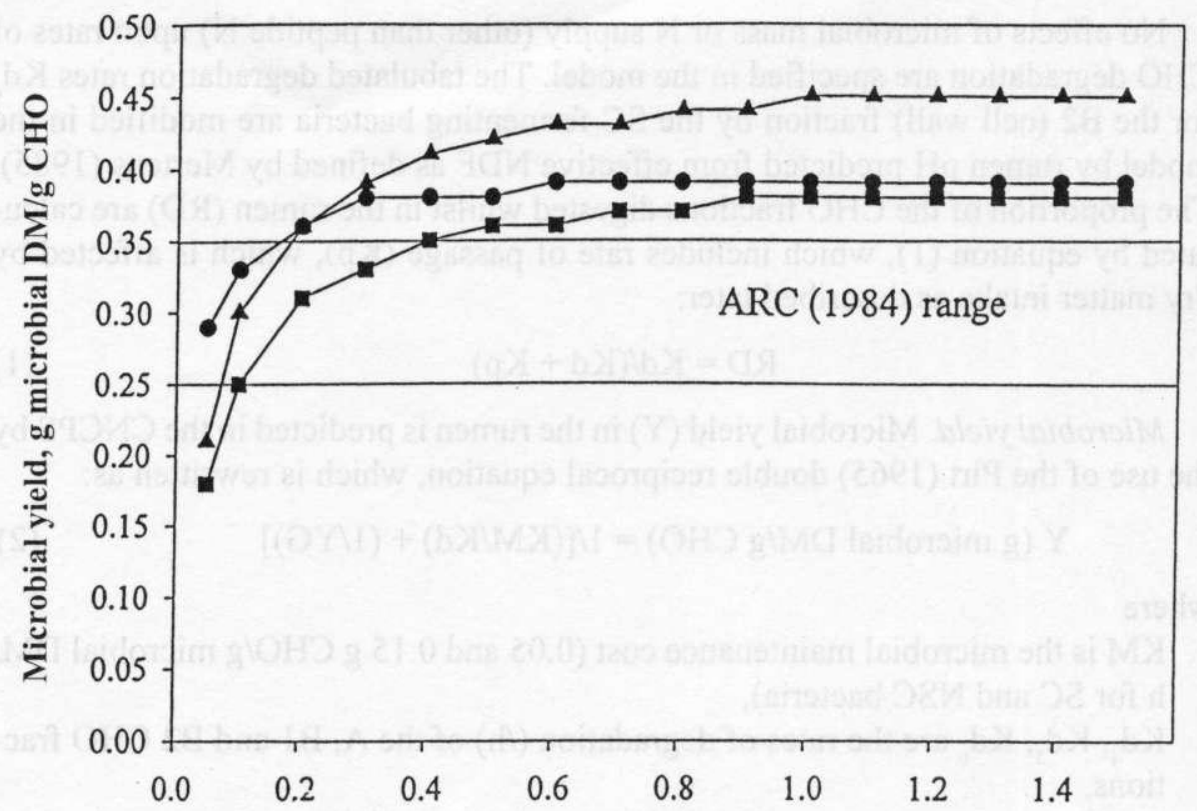

Rate of degradation, /h

Figure 1. Predicted microbial yield in the CNCPS model compared with ARC (1984). Symbols: Y1, equation (3) in text; ( $)$ Y2 or Y3, equation (4) in text; (4) Y2 or Y3, peptide supply nonlimiting

source of peptide) an increase in microbial yield of about $50 \%$ is obtained, in line with other work (Baldwin et al., 1977, 77\%; Dijkstra et al., 1992, 59\%). Predicted microbial yields (allowing for an 18\% improvement in NSC yields due to adequate peptide supply) in the region of 0.3 to $0.4 \mathrm{~g}$ microbial DM/g ruminally degraded carbohydrate $(\mathrm{RDCHO})$ are predicted for feeds such as grass silage, wheat and soyabean, or 30 to $40 \mathrm{~g} \mathrm{~N} / \mathrm{kg} \mathrm{RDCHO}$. Assuming that organic matter apparently digested in the rumen (DOMR) is $85 \% \mathrm{RDCHO}$ (correcting for RDP and fat), this gives values of 26 to $34 \mathrm{~g} \mathrm{~N} / \mathrm{kg}$ DOMR, comparable to the ARC (1984) values, ranging from 23 to $32 \mathrm{~g} \mathrm{~N} / \mathrm{kg}$ DOMR.

This approach to microbial yield is in contrast to the direct effects of feeding level (and indirectly outflow rate) on microbial yield (y) first suggested in ARC (1984) and subsequently redefined in AFRC (1992):

where

$$
y=7.0+6.0\left[1-e^{(-0.35 L)}\right]
$$

$\mathrm{y}$ is as $\mathrm{g}$ microbial CP (MCP)/MJ FME,

$\mathrm{L}$ is $\mathrm{ME}$ intake as multiples of maintenance. 
The NRC (1985) equation for microbial yield (Y) also implies an effect of feeding level, due to the presence of a constant term:

$$
\mathrm{Y}=26.13 \mathrm{TDN}-31.9
$$

where

$\mathrm{Y}$ is g microbial $\mathrm{N} / \mathrm{d}$,

TDN is $\mathrm{kg} / \mathrm{d}$.

Equation (6) which gives values for microbial $\mathrm{N}$ yields of 19.8 to $24.5 \mathrm{~g} \mathrm{~N} / \mathrm{kg}$ TDN ( $=198$ to $245 \mathrm{~g}$ microbial DM/kg TDN, or 124 to $153 \mathrm{~g} \mathrm{MCP} / \mathrm{kg}$ TDN) as TDN intake increases from 5 to $20 \mathrm{~kg} / \mathrm{d}$, (equivalent to feeding levels $\mathrm{L}=1$ to 4 ). However, the term TDN\% used in NRC (1985), fermentable organic matter (FOM) in INRA (1988) and Tamminga et al. (1994), fermentable metabolisable energy (FME) in AFRC (1992), and digestible carbohydrate (DCHO) in Madsen (1985) all describe either the potentially fermentable or digestible energy supply. These estimates are not affected by outflow rate (as they are defined as measured at the maintenance level of feeding) and do not define the actual amounts of nutrients expected to be degraded in the rumen. An exception is ARC (1980), which took a mean value for the proportion of organic matter digested in the rumen (DOMR) of 0.65 of digested OM (DOM). The majority of these systems also specify fixed microbial protein yields per unit of fermentable matter, viz. 93 and $150 \mathrm{~g} \mathrm{MCP} / \mathrm{kg}$ FOM, and $106 \mathrm{~g} / \mathrm{kg}$ DCHO, except AFRC (1992), which has a range of 8 to $12 \mathrm{~g} / \mathrm{MJ}$ FME, dependent upon feeding level.

Nitrogen supply. The degradation of feed proteins is primarily a first-order process in the CNCPS model, but degradation of the resulting peptides is modified by the microbial mass of the NSC fermenting bacteria (NSCBACT) and the rumen liquid outflow rate $(\mathrm{Kl})$. Peptides not captured by the NSC bacteria are presumed to be degraded to ammonia, since there appears to be no computation of peptides escaping from the rumen in the liquid outflow and they are not included in the NAN outflow from the rumen. The CNCPS model does not take into account the effects of low $\mathrm{N}$ availability in the rumen in limiting microbial yield and rates of degradation, as reported by Oldham (1984). Consequently diets low in rumen degradable protein (RDP) can have predicted negative rumen ammonia levels which are biologically impossible (Dijkstra and France, 1996), and predicted amounts of microbial crude protein for which there is an inadequate supply of $\mathrm{N}$. In contrast, the NRC (1985), INRA (1988) and AFRC (1992) models of microbial protein production all limit the amount of MCP synthesised to the estimated amount of $\mathrm{N}$ available to the rumen microbes, thus maintaining proper $N$ stoichiometry in the rumen.

Nitrogen recycling. Endogenous $\mathrm{N}$ input into the rumen (urea and saliva proteins in saliva and urea absorption through the rumen walls) may be a significant factor when dietary $\mathrm{N}$ levels are low, but is only represented in a proportion of 
rumen models (Dijkstra and France, 1996). The CNCPS model uses the NRC (1985) $\mathrm{N}$ recycling function (Yr), calculated as \% of total dietary $\mathrm{N}$ intake, as shown in equation (7):

where

$$
\mathrm{Yr}=121.7-12.01 \mathrm{X}+0.3235 \mathrm{X}^{2}
$$

$\mathrm{Yr}$ is urea recycled ( $\%$ of $\mathrm{N}$ intake),

$\mathrm{X}$ is intake of crude protein ( $\%$ of diet DM).

This quadratic equation has a minimum value of $10 \%$ at $16 \%$ dietary crude protein in the dry matter, comparable to the values assumed by other models in their estimation of mean efficiency of $\mathrm{N}$ capture by rumen microbes. However, as dietary crude protein level rises above $16 \%$ (common in modern dairy cow diets) it predicts a reduction in $\mathrm{N}$ recycling, which is unrealistic. Urea recycling also features (as $\mathrm{g} \mathrm{N} / \mathrm{d}$, not $\%$ of $\mathrm{CP}$ ) in the calculation of rumen ammonia levels in an equation which can yield negative values. This is similar to the Scandinavian AAT (Madsen, 1985) and Dutch DVE (Tamminga et al., 1994) models which calculate and recommend optimal rumen $\mathrm{N}$ balances, but do not limit microbial protein synthesis by $\mathrm{N}$ supply. The presumption apparently is that deficiencies of rumen $\mathrm{N}$ supply in dairy cow diets in practice are rare, which can be questioned when maize silage and cereal based diets for cattle are in such widespread use. Recycling of microbial N, particularly by protozoa, does not feature in the CNCPS either, although Dijkstra (1994) has assembled a comprehensive model of protozoal $\mathrm{N}$ recycling.

Rumen $p H$. Although Russell et al. (1992) did not give a function to predict rumen $\mathrm{pH}$, the CNCPS v. 3.0 version of the CNCPS model predicts a drop in $\mathrm{pH}$ value below the norm of 6.46, based on Pitt et al. (1996):

$$
\text { If } \mathrm{eNDF}<26.3 \%, \mathrm{pH}=5.46+0.038 \mathrm{eNDF} \% \text {, otherwise } \mathrm{pH}=6.46
$$

Russell et al. (1992) did not adjust SC degradation rate when $\mathrm{pH}$ is lowered below their stated optimum of 6.725 , but instead reduced maximum microbial yicld (YG) for both NSC and SC bacteria when eNDF was below $20 \%$ in DM, using:

$$
\text { New } Y G=Y G-0.025(20-\mathrm{eNDF} \%)
$$

Predicted rumen $\mathrm{pH}$ has subsequently been used in revisions of the model to modify microbial maintenance (KM), maximum microbial yield (YG), realised microbial yield ( $\mathrm{Y}$ ) and rate of $\mathrm{CHO}$ degradation $\mathrm{Kd}$, as discussed later.

Liquid and solid outflow rates. Rumen modelling results are sensitive to the passage rates assumed. In most models, passage of material is assumed to be partly with the fluid phase and partly with the solid phase. The CNCPS assumes that 
soluble sugars and acids are washed out with the particles, and calculates solid outflow rates $(\mathrm{Kp})$ for forages and concentrates separately:

$$
\begin{gathered}
\mathrm{Kp}[\text { forages }], \% / \mathrm{h}=0.388+0.02 \mathrm{DMI} / \mathrm{W}^{0.75}+0.0002(\text { forage } \% \text { in } \mathrm{DM})^{2} \\
\mathrm{Kp}[\text { concentrates }], \% / \mathrm{h}=-0.424+1.45 \mathrm{Kp}[\text { forage }]
\end{gathered}
$$

where

\section{DMI is in $\mathrm{g} / \mathrm{d}$,}

$\mathrm{W}$ is in $\mathrm{kg}$.

The coefficient 0.002 on DMI in the equation on p. 3567 of Sniffen et al. (1992) is confirmed by the senior author of that paper as an error, since it occurs as 0.02 in the spreadsheet, which then gives acceptable values for $K \mathrm{p}[$ forages] as $\% / \mathrm{h}$. The corrected equation, equation (10), then gives the expected effect of significantly lower values for $\mathrm{RD}$ predicted by equation (1), as $\mathrm{Kp}$ (forages) and $\mathrm{Kp}$ (concentrates) increase with feed dry matter intake.

Both the calculated Kp values are adjusted for feed particle size by a correction factor (Af) using diet effective NDF (eNDF\%) values:

$$
\begin{gathered}
\text { Af }[\text { forages }]=100 /(\text { eNDF } \%+70) \\
\text { Af }[\text { concentrates }]=100 /(\text { eNDF } \%+90)
\end{gathered}
$$

The term eNDF\% is defined in the footnotes to Tables 2 and 3 of Sniffen et al. (1992), p. 3569-3570 as 'the proportion of NDF that is effective in meeting the animal's fibre requirements', whilst the relevant columns of the tables are headed ' $\%$ of NDF'. Values ranging from $60-98 \%$ for forages and $4-100 \%$ for concentrates are listed. However, use of that definition of eNDF results in Af values of the order of 0.6 for forages and large downward corrections to both $\mathrm{Kp}$ values. This definition is in conflict with the definition of eNDF\% used in the equations which adjust rumen $\mathrm{pH}$ and microbial yield in subsequent revisions of the CNCPS model. Examination of the printed output from the model shows that the correct definition of eNDF\% for use in equations (12) and (13) is eNDF as \% of DM, which is the Tables 2 and 3 value times NDF \% in DM. The senior author of Sniffen et al. (1992) has subsequently confirmed that this interpretation is correct.

Russell et al. (1992) use a term for liquid outflow rate (KI) in the following equation for peptide uptake (PEPUP): where

$$
\text { PEPUP }=(\text { KUP } \times \text { NSCBACT }) /[\text { RDPEP }(\text { KUP } \times \text { NSCBACT }+ \text { K1 })]
$$

$\mathrm{K} 1$ is $\% / \mathrm{h}$ for a steady state rumen.

The companion paper which is referred to (Sniffen et al., 1992) gives no guidance on the calculation of $\mathrm{Kl}$ other than saying that it is an input to the model. However, Pitt et al. (1996) dealing with the prediction of VFA and rumen $\mathrm{pH}$, quote a function for $\mathrm{Kl}$ attributed to Fox et al. (1990): 


$$
\mathrm{Kl}(/ \mathrm{d})=1.059+0.0458 \mathrm{DMI} / \mathrm{W}
$$

where

$\mathrm{KI}$ is as a decimal per day for a steady state rumen,

$\mathrm{DMI}$ is as $\mathrm{g} / \mathrm{d}$,

$\mathrm{W}$ is in $\mathrm{kg}$.

The values obtained for solid $(\mathrm{Kp})$ and associated liquid $(\mathrm{Kl})$ outflow rates for diets of various forage:concentrate proportions are shown in Table 1 and those for $\mathrm{Kp}$ in Figure 2, where they are compared with the solid outflow rates of AFRC (1993).

TABLE 1

Solid outflow rates $(\mathrm{Kp}, / \mathrm{h})$, for forage $(\mathrm{F})$ and concentrates $(\mathrm{C})$, and liquid outflow rates $(\mathrm{Kl}, \mathrm{h})$ in the CNCPS model compared to AFRC (1993)

\begin{tabular}{|c|c|c|c|c|c|c|c|c|c|c|c|}
\hline \multirow[t]{2}{*}{ DMI } & \multirow[b]{2}{*}{$\mathrm{xM}$} & \multirow{3}{*}{$\begin{array}{c}\text { Liquid } \\
\text { outflow } \\
\mathrm{Kl}\end{array}$} & \multicolumn{7}{|c|}{ Solid outflow rate $\mathrm{Kp}$ for forage $\%$ diet $\mathrm{DM}$} & \multirow{3}{*}{$\begin{array}{l}60 \% \mathrm{~F}, \\
40 \% \mathrm{C} \\
\text { Mean }\end{array}$} & \multirow{3}{*}{$\begin{array}{l}\text { AFRC } \\
(1993) \\
F+C\end{array}$} \\
\hline & & & \multicolumn{2}{|c|}{$40 \%$} & \multicolumn{2}{|c|}{$60 \%$} & \multicolumn{2}{|c|}{$80 \%$} & \multirow{2}{*}{$\begin{array}{c}100 \% \\
\mathrm{~F}\end{array}$} & & \\
\hline $\mathrm{kg} / \mathrm{d}$ & $\mathrm{L}$ & & F & $\mathrm{C}$ & F & C & $\mathrm{F}$ & $\mathrm{C}$ & & & \\
\hline 6 & 1 & .063 & .017 & .026 & .021 & .026 & .027 & .017 & .034 & 0.023 & .019 \\
\hline 12 & 2 & .082 & .027 & .041 & .031 & .041 & .037 & .031 & .044 & 0.035 & .052 \\
\hline 18 & 3 & 101 & .037 & .055 & .041 & .055 & .046 & .046 & .054 & 0.047 & .077 \\
\hline 24 & 4 & .120 & .047 & .069 & .051 & .069 & .056 & .060 & .064 & 0.058 & .096 \\
\hline
\end{tabular}

Predicted liquid outflow rates are about three times the solid outflow rates at low feeding levels, reducing to twice at higher feeding levels. For typical dairy cow diets with 40 to $60 \%$ of forage, the solid outflow rates $(\mathrm{Kp})$ range from 0.017 to $0.069 / \mathrm{h}$ in Table 1 . The weighted means are 0.6 to 0.7 of the AFRC (1993) diet outflow rates, except at the maintenance feeding levels. Note should also be taken of the adoption of fixed solid outflow rates for dairy cows of $0.06 / \mathrm{h}$ in INRA (1988) and Tamminga et al. (1994), and $0.08 / \mathrm{h}$ in Madsen (1985). These differences in rumen solid outflow rates have important theoretical implications for the amount of dry matter required to be held in the rumen and the volume of the rumen at different feed intakes, when a steady state is assumed.

The low outflow rates also affect the predicted digestibility of feed fractions in the rumen (RD), defined by equation (1). For a typical $\mathrm{Kd}$ value of $0.1 / \mathrm{h}$ for the cell wall or B2 protein fraction, and a diet of $60: 40$ forage to concentrates, RD is predicted to be 0.73 to 0.61 for feeding levels $L=1$ to 4 times maintenance, comparable with the ARC (1980) mean value for DOMR of 0.65 . When $\mathrm{Kd}=0.2 / \mathrm{h}$, as for starch, then $R D$ varies from 0.84 to 0.76 . This prediction of a higher proportion of OM digested in the rumen could be a contributory cause of the high levels of predicted VFA production found by Pitt et al. (1996). 


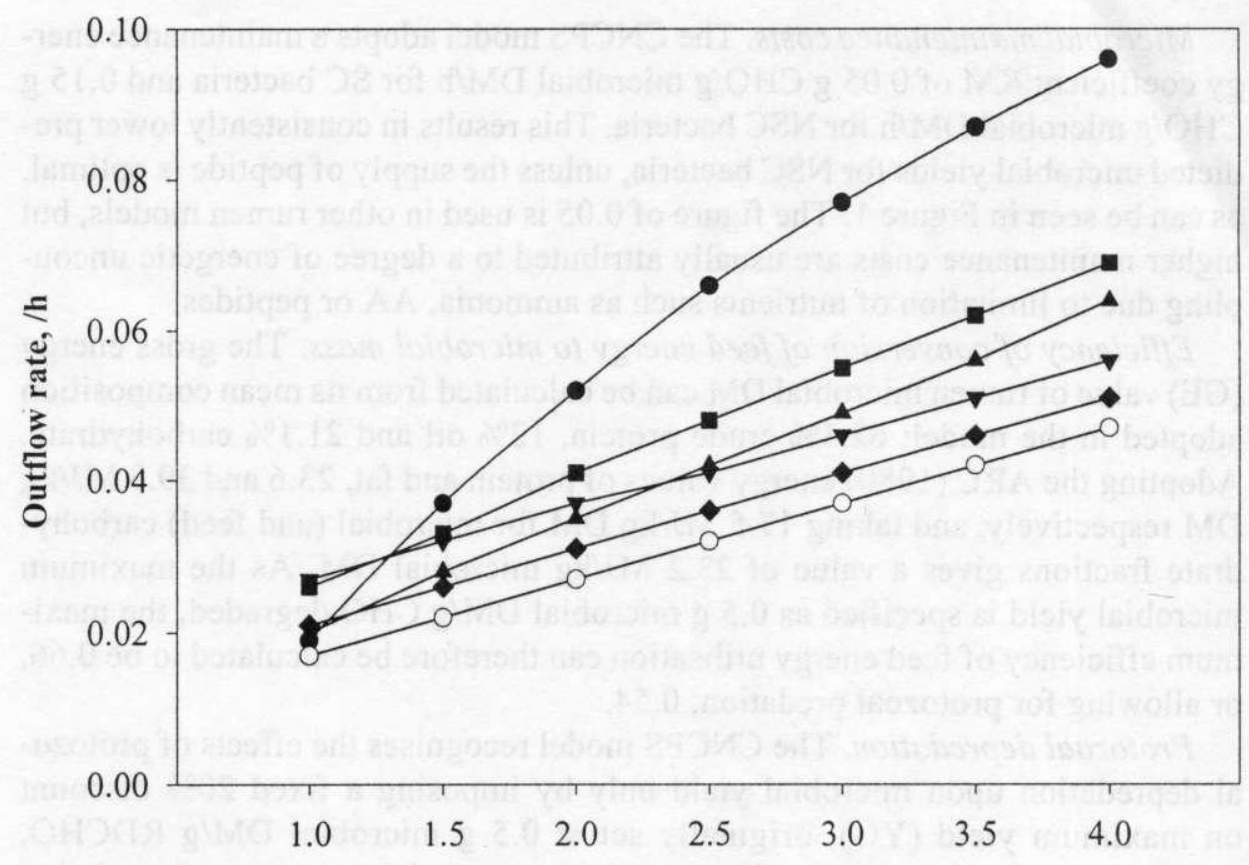

Feeding level L

Figure 2. Solid outflow rates in the CNCPS model compared with AFRC (1993). Symbols (see

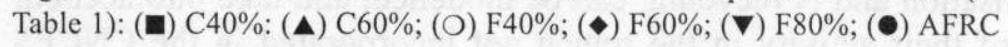

In steady state situations, and in the absence of microbial engulfment and lysis, microbial growth rate equals the solid outflow rate. The CNCPS model assumes that the fractional growth rate of SC and NSC rumen bacteria is equal to the fractional degradation rate of SC and NSC respectively, which presents some biological problems (Dijkstra and France, 1996). They pointed out that the tabulated fractional degradation rate of SC can be as low as $0.02 / \mathrm{h}$ (Sniffen et al., 1992, Tables 4, 5 and 6) which is likely to be lower than the lowest particle outflow rate, so that the survival of SC bacteria would require their attachment to newly ingested particles with a low probability of passage. The highest tabulated degradation rate, $350 \% / \mathrm{h}$, for the A fraction of NSC (sugar) is higher than the maximum growth rate of rumen bacteria and is therefore biologically impossible. These contradictions arise from the adoption of the simplifying assumption that microbial growth is dependent upon the rate of $\mathrm{CHO}$ degradation, whereas the latter is the result of microbial activity leading to microbial growth, as in other models of the rumen. 
Microbial maintenance costs. The CNCPS model adopts a maintenance energy coefficient $\mathrm{KM}$ of $0.05 \mathrm{~g} \mathrm{CHO} / \mathrm{g}$ microbial $\mathrm{DM} / \mathrm{h}$ for $\mathrm{SC}$ bacteria and $0.15 \mathrm{~g}$ $\mathrm{CHO} / \mathrm{g}$ microbial $\mathrm{DM} / \mathrm{h}$ for NSC bacteria. This results in consistently lower predicted microbial yields for NSC bacteria, unless the supply of peptide is optimal, as can be seen in Figure 1. The figure of 0.05 is used in other rumen models, but higher maintenance costs are usually attributed to a degree of energetic uncoupling due to limitation of nutrients such as ammonia, AA or peptides.

Efficiency of conversion of feed energy to microbial mass. The gross energy (GE) value of rumen microbial DM can be calculated from its mean composition adopted in the model: $62.5 \%$ crude protein, $12 \%$ oil and $21.1 \%$ carbohydrate. Adopting the ARC (1980) energy values of protein and fat, 23.6 and $39.3 \mathrm{MJ} / \mathrm{kg}$ DM respectively, and taking $17.5 \mathrm{MJ} / \mathrm{kg} \mathrm{DM}$ for microbial (and feed) carbohydrate fractions gives a value of $23.2 \mathrm{MJ} / \mathrm{kg}$ microbial DM. As the maximum microbial yield is specified as $0.5 \mathrm{~g}$ microbial $\mathrm{DM} / \mathrm{g}$ CHO degraded, the maximum efficiency of feed energy utilisation can therefore be calculated to be 0.66 , or allowing for protozoal predation, 0.54 .

Protozoal depredation. The CNCPS model recognises the effects of protozoal depredation upon microbial yield only by imposing a fixed $20 \%$ discount on maximum yield ( $\mathrm{YG}$ ), originally set at $0.5 \mathrm{~g} \mathrm{microbial} \mathrm{DM} / \mathrm{g} \mathrm{RDCHO}$, but does not take the variation in microbial turnover due to protozoal predation or the contribution of protozoa to microbial outflow into account. Dijkstra (1994) and Dijkstra et al. (1997) have shown that the effects of protozoa in the rumen on nutrient utilisation and $\mathrm{N}$ recycling can be modelled, and take into account many aspects of their activity in the rumen not incorporated in the CNCPS rumen model.

Metabolism of fats and long chain fatty acids. The CNCPS model assumes that no long chain fatty acids (LCFA) are taken up by microbes, and that $100 \%$ of dietary fat escapes degradation in the rumen, thus implying that no glycerol is released in the rumen. However, it is known that feed lipids are rapidly hydrolysed and hydrogenated by rumen microbes to glycerol and saturated LCFA (Dijkstra and France, 1996). The glycerol released is normally assumed to be degraded in the rumen at a rate similar to sugar. LCFA are only metabolised slowly by rumen microbes, but some are taken up (Bauchart et al., 1990). Consequently, the total flow of LCFA to the intestines is the sum of LCFA arising from feed and microbial matter, i.e. it is normally greater than the dietary fat input because of de novo fat synthesis by the rumen bacteria.

Variations in composition of rumen microbes. The chemical composition of mixed rumen bacteria, as reviewed by Clark et al. (1992), was found to be highly variable, with crude protein varying from $30-66 \%$, with inverse variation in bacterial polysaccharides. The amino acid composition of the bacterial protein was fairly constant, except for variations in histidine and methionine The composi- 
tion of protozoa is also known to differ from that of rumen bacteria (Czerkawski, 1976), whilst the proportion of protozoa in the microbial population varies with the diet. The nucleic acid content of microbial cell dry matter in the CNCPS is taken as 15\%, based on Purser and Buechler (1966). Nucleic acids are taken to have an $\mathrm{N}$ content of $15 \%$, equivalent to $93.75 \%$ crude protein. This represents a deduction of about $16 \%$ for nucleic acids from microbial protein, compared to $25 \%$ in AFRC (1992) based on a 1992 EEC Ring Test.

The microbial storage polysaccharide content is probably the most variable component of microbial dry matter (Storm and Ørskov, 1983; Dijkstra and France, 1996) and it is an important component of NSC bacterial outflow from the rumen. Dijkstra et al. (1992) varied the microbial polysaccharide level according to dietary characteristics. Yet most published rumen models (including the CNCPS) have assumed a constant composition of microbial non-protein organic matter. The CNCPS model recognises the effects of protozoal depredation upon microbial yield, but does not then take the contribution of protozoa to microbial outflow into account.

\section{DEVELOPMENTS IN THE RUMEN MODEL SINCE 1992}

Since its publication in 1992, the CNCPS model, as applied to beef cattle, has been adopted in the NRC (1996) publication Nutrient Requirements of Beef Cattle. The latter publication has been used to cross check the core rumen equations, resulting in subsequent modification and updating of the model. Pitt et al. (1996) also proposed a number of modifications to the model. These were primarily concerned with the effects of low rumen $\mathrm{pH}$ (possibly due to the low fibre diets used in US beef feed lots) upon rumen microbial efficiency, but equations were also suggested for the prediction of both the proportions and amount of VFA produced, and the amounts of methane and carbon dioxide produced (not included in CNCPS v.3.0). A current research version of the model (CNCPSREV) was made available to the author by Dr D.G. Fox of Cornell University. This incorporates some of the equations proposed by Pitt et al. (1996). Subsequently, an updated model (version 3.1) of the CNCPS was promulgated as part of the software package CPM Dairy, made available in the autumn of 1998. This was a joint activity by Fox and co-workers at Cornell University, Chalupa at Pennsylvania University and Sniffen at the W.H. Miner Agricultural Research Institute, Chazy NY. The other component of that software package is a modified NRC (1988) dairy cow model. The package was written in computer code, rather than utilising a standard spreadsheet as the CNCPS did. These developments, which mostly affect the supply model, are reviewed below. 
Central role of effective NDF

In version 3.0 of the CNCPS, the maximum microbial yield of the SC bacteria (YG $\leq 0.4 \mathrm{~g}$ microbial $\mathrm{DM} / \mathrm{g}$ CHO fermented) is corrected downwards by equation (9) by $0.025 \mathrm{~g} / \mathrm{g}$ per $1 \%$ of eNDF when less than $24.5 \%$ of diet dry matter, implying an effect of $\mathrm{pH}$ as well as that due to SC:NSC substrate proportions. However, as eNDF is now used in CNCPSREV (as suggested by Pitt et al., 1996) and CPM Dairy to predict rumen $\mathrm{pH}$, eNDF also affects the values of KM1, YG1, $\mathrm{Y} 1, \mathrm{Y} 2$ and $\mathrm{Y} 3$. Reductions in the values of $\mathrm{Y}$ also lead to the calculation of reduced values for Kd for all types of carbohydrate. This means that eNDF\% (for values below $24.5 \%$ in diet $\mathrm{DM}$ ) is affecting directly ruminally degraded $\mathrm{CHO}$ (RD) and hence energy supply (as TDN, DE, ME and net energy) and microbial protein (and metabolisable protein) supply to the animal. Such an over reliance upon one dietary parameter in a rumen metabolism model seems unwise, particularly as the routine determination of eNDF presents some difficulties. However, Mertens (1997) reviewed the subject of measuring the physical structure of feeds for cows and redefined his original definition of eNDF (Mertens, 1985) to become physically effective NDF (peNDF), which has been adopted in the CPM Dairy version of the CNCPS. The new definition results in values which average $3 \%$ above the eNDF values in the earlier CNCPS v.3.0 Feed Library (W. Chalupa, personal communication). As a consequence, some of the equations which are driven by eNDF have had to be adjusted.

Particle size adjustment to solid outflow rates. Predicted outflow rates of forage and concentrate particles are adjusted according to their eNDF content by means of equations (12) and (13). Because of the form of these equations, the effect of an increase of 3 percentage units by replacing eNDF\% by peNDF\% will be a very small reduction in Af of the order of only 0.03 . Consequently, equations (12) and (13) are retained unchanged in the CPM Dairy version of CNCPS.

Prediction of rumen $p H$. The CNCPS v. 3.0 version of the model predicts a drop in $\mathrm{pH}$ value below the norm of 6.46 when eNDF is less than $26.3 \%$ of diet dry matter using equation (8) published subsequently by Pitt et al. (1996). Russell et al. (1992) did not adjust SC degradation rate when $\mathrm{pH}$ falls below their stated optimum of 6.725 , but predicted that parameter direct from diet eNDF\%. However, the NRC (1996) beef model and the latest version examined (CNCPSREV) use a slightly modified equation (8) to predict rumen $\mathrm{pH}$, which uses a lower eNDF\% limit:

$$
\text { If eNDF }<24.5 \% \text {, rumen } \mathrm{pH}=5.425+0.04229 \mathrm{eNDF} \%
$$

which still implies a maximum (and normal) rumen $\mathrm{pH}$ of 6.46 as in Pitt et al. (1996). To accommodate the revision of feed and diet eNDF\% values to the higher peNDF\% adopted in the CPM Dairy version, the minimum level at which equation 
(16) to predict rumen $\mathrm{pH}$ comes into action has been raised from 24.5 to $27.5 \%$, according to the CPM Dairy Help file. However, a listing of the equations in CPM Dairy (W. Chalupa, personal communication) has the following equations for the prediction of rumen $\mathrm{pH}$ from peNDF expressed as a decimal:

$$
\text { Rumen } \mathrm{pH}=(1-\mathrm{G}) *(5.25+4.229 \mathrm{peNDF})+6.47 \mathrm{G}
$$

where

$$
\mathrm{G}=1 /\{1+\exp [-20 *(\operatorname{peNDF}-0.2639)]\}
$$

Equation (17) is curvilinear, but over the range for peNDF values of 15 to $26 \%$, (equivalent to 12 to $23 \% \mathrm{eNDF}$ ) gives predicted $\mathrm{pH}$ values quite close to the equation due to Pitt et al. (1996), (Figure 3), and thereafter deviates, becoming asymptotic at $\mathrm{pH}=6.47$ for peNDF values of $32-33 \%$, whereas the linear equation (16) ceases at a value of $24.5 \%$ eNDF\% (=27.5\% peNDF). Equation (16), which has an upper limit, made the running of optimising procedures for diet formulation difficult, so the continuous function, equation (17), was derived to solve this problem.

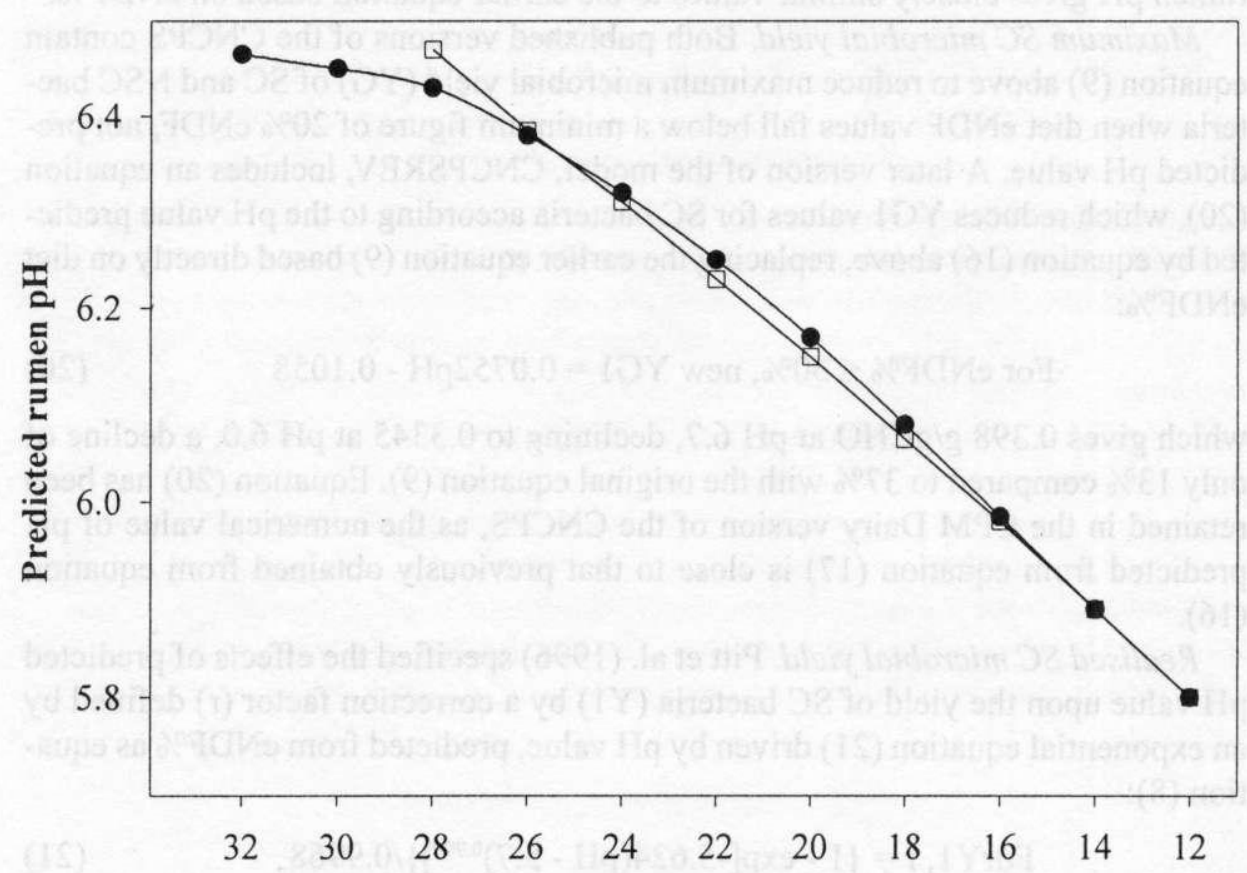

PeNDF\% or eNDF\% in diet DM

Figure 3. Prediction of rumen $\mathrm{pH}$ from eNDF\% as Pitt et al. (1996) ( $\square$ ) and peNDF\% as CPM Dairy (1998) 
Effect of rumen $p H$ upon rumen microbial parameters

Predicted rumen $\mathrm{pH}$ has subsequently been used to modify maximum microbial yield (YG1) of NSC bacteria, instead of using eNDF\% directly. Adjustments to microbial maintenance $(\mathrm{KMl})$ and realised microbial yield $(\mathrm{Y})$ based on predicted rumen $\mathrm{pH}$ suggested by Pitt et al. (1995) have been adopted, and also consequential corrections to the degradation rates $\mathrm{Kd}_{4}, \mathrm{Kd}_{5}$ and $\mathrm{Kd}_{6}$ for both $\mathrm{SC}$ and NSC CHO.

SC microbial maintenance. Pitt et al. (1996) suggested a linear equation (19) to modify slightly microbial maintenance (KM1) for SC bacteria according to predicted $\mathrm{pH}$ value from equation (8):

$$
\text { New KM1 }=0.1409-0.0135 \mathrm{pH}
$$

Declines in rumen $\mathrm{pH}$ value increase $\mathrm{KM} 1$ slightly from 0.05 at the normal $\mathrm{pH}$ 6.7 , rising to 0.064 at $\mathrm{pH}$ 5.7. This equation has been retained unmodified in the CPM Dairy version of CNCPS, as the revised equation (17) for the prediction of rumen $\mathrm{pH}$ gives closely similar values to the earlier equation based on $\mathrm{cNDF} \%$.

Maximum SC microbial yield. Both published versions of the CNCPS contain equation (9) above to reduce maximum microbial yield (YG) of SC and NSC bacteria when diet eNDF values fall below a minimum figure of $20 \% \mathrm{eNDF}$, not predicted $\mathrm{pH}$ value. A later version of the model, CNCPSREV, includes an equation (20), which reduces $\mathrm{YG} 1$ values for $\mathrm{SC}$ bacteria according to the $\mathrm{pH}$ value predicted by equation (16) above, replacing the earlier equation (9) based directly on diet eNDF\%:

$$
\text { For eNDF } \% \leq 30 \% \text {, new YG1 }=0.0752 \mathrm{pH}-0.1058
$$

which gives $0.398 \mathrm{~g} / \mathrm{gCHO}$ at $\mathrm{pH} 6.7$, declining to 0.3345 at $\mathrm{pH} 6.0$, a decline of only $13 \%$ compared to $37 \%$ with the original equation (9). Equation (20) has been retained in the CPM Dairy version of the CNCPS, as the numerical value of $\mathrm{pH}$ predicted from equation (17) is close to that previously obtained from equation (16).

Realised SC microbial yield. Pitt et al. (1996) specified the effects of predicted $\mathrm{pH}$ value upon the yield of SC bacteria (Y1) by a correction factor (r) defined by an exponential equation (21) driven by $\mathrm{pH}$ value, predicted from $\mathrm{eNDF} \%$ as equation (8):

$$
\text { ForY } 1, \mathrm{r}=\left\{1-\exp \left[-5.624(\mathrm{pH}-5.7)^{0.909}\right]\right\} / 0.9968
$$

The identical equation is to be seen in the NRC (1996), beef version of the model, p.122, equation (3), but in the CPM Dairy version of the CNCPS, the power factor of 0.909 has been omitted from the term $(\mathrm{pH}-5.7)$, where $\mathrm{pH}$ is now predicted from peNDF\% as equation (17), whilst the other constants are retained. 
The effect is very small $(<0.01)$ but shifts the $\mathrm{pH}$ value at which a decline in Y1 starts to 6.7 not 6.9 as previously.

Realised NSC microbial yield. Pitt et al. (1996) also specified the effects of predicted $\mathrm{pH}$ value upon the yield of NSC bacteria (Y2 and $\mathrm{Y} 3$ ) by their equation (7), similar in structure to that given for SC bacteria, equation (21), but with different constants:

$$
\text { For } \mathrm{Y} 2 \text { and } \mathrm{Y} 3, \mathrm{r}=\left\{1-\exp \left[-0.693(\mathrm{pH}-4.5)^{1.732}\right]\right\} / 0.9373
$$

This equation predicts a curvilinear reduction in Y2, Y3 values to 0.7 of their starting value at $\mathrm{pH}$ 6.7, but does not appear does to feature in the CPM Dairy version of the CNCPS. Correction factors ( $\mathrm{r}$ for Y1, Y2), modified microbial maintenance (KM1) and maximum microbial yields (YG1, YG2), using the relevant functions for SC and NSC bacteria, are shown in Figure 4.

Liquid outflow rate and peptide uptake. Equation (15) for liquid outflow rate was omitted from NRC (1996), as equation (14) for peptide uptake (PEPUP) was simplified to PEPUP $=$ RDPEP. Equation $(15)$ has been retained in the CPM Dairy

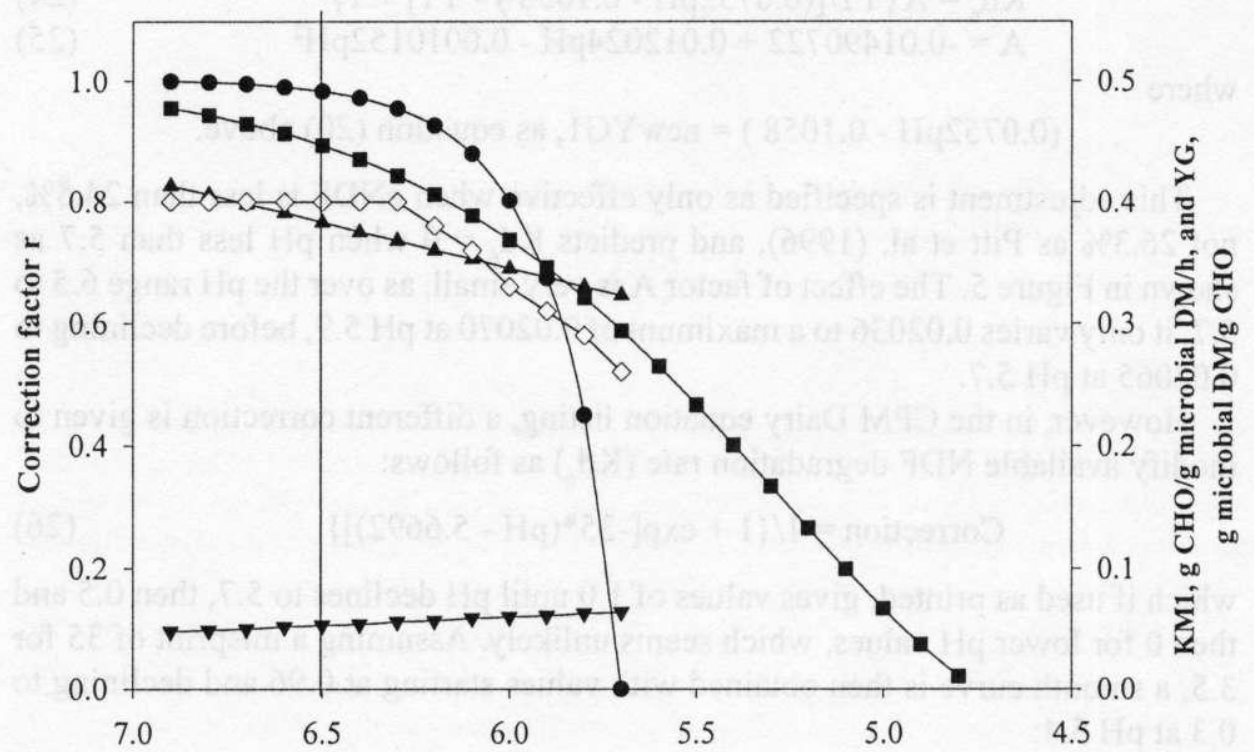

Predicted rumen $\mathrm{pH}$

Figure 4. Effect of predicted $\mathrm{pH}$ upon microbial yields. Symbols: $(\bullet)$ correction factor for yield of SC bacteria as Pitt et al. (1996); ( ) correction factor for yield of NSC bacteria as Pitt et al. (1996); ( $\mathbf{\nabla})$ SC microbial maintenance as Pitt et al. (1996); ( $\mathbf{\Lambda}$ ) maximum microbial yield as CNCPSREV, equation (20) in text; $(0)$ maximum microbial yield from eNDF $<20 \%$, as Russell et al. (1992) and NRC (1996), equation (9) in text 
version of the CNCPS, although recalculated to give percent per hour $(\% / \mathrm{h})$, not decimal per day.

Rate of carbohydrate degradation. Because of the effects of rumen $\mathrm{pH}$ on microbial maintenance and maximum and realised microbial yield described above by equations (19) - (22), the effective rates of degradation of the $\mathrm{SC}\left(\mathrm{Kd}_{6}\right)$ and NSC $\left(\mathrm{Kd}_{4}\right.$ and $\left.\mathrm{Kd}_{5}\right)$ carbohydrate fractions must be adjusted to match these new values. This can be done by substituting in a rearranged equation (2), as follows for the SC CHO fraction:

$$
\mathrm{Kd}_{6}=(\mathrm{KM} 1 * \mathrm{Y} 1 * \mathrm{YG} 1) /(\mathrm{YG} 1-\mathrm{Y} 1)
$$

Equation (4) of Pitt et al. (1996) has added the term KM1*YGl to equation (23), which is not explained. As KMl is set at 0.05 and $\mathrm{YGl}$ at 0.40 , the value of that term is $0.05 * 0.4=0.02$, identical to an unexplained term of 0.02 in equation (2) of NRC (1996), p.122.

For eNDF values greater than $24.5 \%$, both NRC (1996) and CNCPSREV give two equations to modify $\mathrm{Kd}_{6}$ according to predicted rumen $\mathrm{pH}$ :

$$
\begin{aligned}
& \mathrm{Kd}_{6}=\mathrm{A}\{\mathrm{Y} 1 /[(0.0752 \mathrm{pH}-0.1058)-\mathrm{Y} 1]+1\} \\
& \mathrm{A}=-0.01490722+0.012024 \mathrm{pH}-0.0010152 \mathrm{pH}^{2}
\end{aligned}
$$

where

$$
(0.0752 \mathrm{pH}-0.1058)=\text { newYGl, as equation }(20) \text { above. }
$$

This adjustment is specified as only effective when eNDF is less than $24.5 \%$, not $26.3 \%$ as Pitt et al. (1996), and predicts $\mathrm{Kd}_{6}=0$ when $\mathrm{pH}$ less than 5.7 as shown in Figure 5. The effect of factor $\mathrm{A}$ is very small, as over the $\mathrm{pH}$ range 6.5 to 5.7 , it only varies 0.02036 to a maximum of 0.02070 at $\mathrm{pH} 5.9$, before declining to 0.02065 at $\mathrm{pH} 5.7$.

However, in the CPM Dairy equation listing, a different correction is given to modify available NDF degradation rate $\left(\mathrm{Kd}_{6}\right)$ as follows:

$$
\text { Correction }=1 /\left\{1+\exp \left[-35^{*}(\mathrm{pH}-5.6692)\right]\right\}
$$

which if used as printed, gives values of 1.0 until $\mathrm{pH}$ declines to 5.7 , then 0.5 and then 0 for lower $\mathrm{pH}$ values, which seems unlikely. Assuming a misprint of 35 for 3.5 , a smooth curve is then obtained with values starting at 0.96 and declining to 0.3 at $\mathrm{pH} 5.4$ :

$$
\text { Correction }=1 /\left\{1+\operatorname{cxp}\left[-3.5^{*}(\mathrm{pH}-5.6692)\right]\right\}
$$

Assuming a maximum value for $\mathrm{Kd}_{6}$ of $0.06 / \mathrm{h}$, the effect of this correction is also shown in Figure 5 . The curve does not now have an unlikely maximum of 0.073 at $\mathrm{pH} 6.3$ nor docs it decline to zero at $\mathrm{pH} 5.7$ as predicted by the NRC (1996) function, but predicts a value for $\mathrm{Kd}_{6}$ of $0.03 / \mathrm{h}(0.5$ of start value) at $\mathrm{pH}$ 5.7 , reaching a value of nearly zero at $\mathrm{pH} 4.3$. 


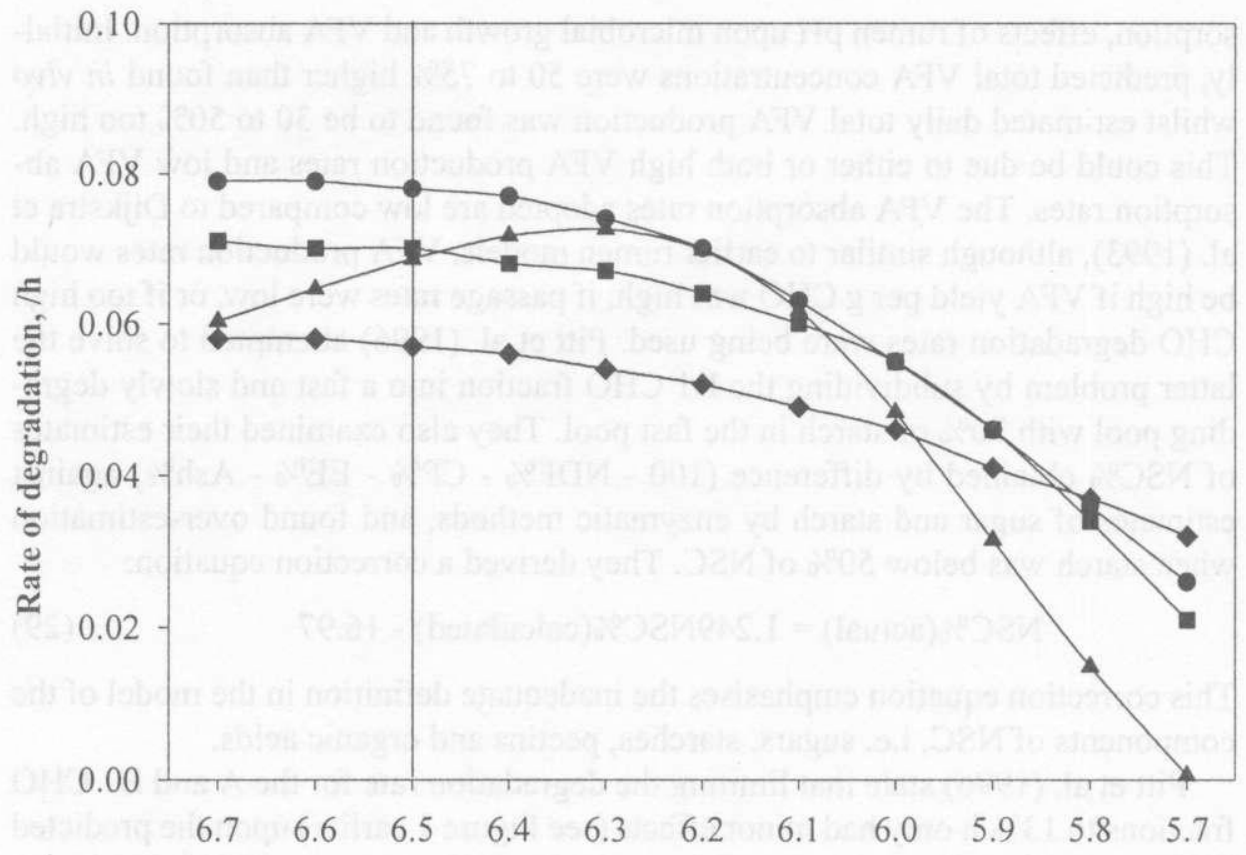

\section{Predicted rumen $\mathrm{pH}$}

Figure 5. Effect of rumen $\mathrm{pH}$ on rate of degradation (Kd6) of cell walls $(\mathrm{SC})$, with the original value of Kd6 taken as 0.06. Symbol: (-) Pitt et al. (1996) equations (1), (2), (3) and (4); (酒) CNCPSREV spreadsheet ex Cornell as at 10/97; (A) NRC (1996), p. 122, equations (1), (2), (3), (4) and (5); (\$) CPM Dairy equation listing, equation (26) in text

\section{Prediction of VFA production}

The current CNCPS model does not include a quantitative representation of VFA in the rumen, although the well recognised acronym VFA appears in an equation defining the quantitative sum of ruminally degraded carbohydrate (RDC) fractions $\mathrm{A}, \mathrm{B} 1$ and $\mathrm{B} 2$ :

$$
\mathrm{VFA}=\mathrm{RDCA}+\mathrm{RDCB} 1+\mathrm{RDB} 2
$$

This equation can easily be misunderstood, as it omits the substantial losses of carbon dioxide and methane arising from microbial fermentation of both SC and NSC carbohydrates. Pitt et al. $(1995 ; 1996)$ have developed a VFA sub-model of the CNCPS model using the same feed description and inputs. Their sub-model predicts acetate, propionate, butyrate, lactate and methane production, VFA ab- 
sorption, effects of rumen $\mathrm{pH}$ upon microbial growth and VFA absorption. Initially, predicted total VFA concentrations were 50 to $75 \%$ higher than found in vivo whilst estimated daily total VFA production was found to be 30 to $50 \%$ too high. This could be due to either or both high VFA production rates and low VFA absorption rates. The VFA absorption rates adopted are low compared to Dijkstra et al. (1993), although similar to earlier rumen models. VFA production rates would be high if VFA yield per $\mathrm{g}$ CHO was high, if passage rates were low, or if too high CHO degradation rates were being used. Pitt et al. (1996) attempted to solve the latter problem by subdividing the $\mathrm{Bl}$ CHO fraction into a fast and slowly degrading pool with $70 \%$ of starch in the fast pool. They also examined their estimates of NSC \% obtained by difference (100 - NDF\% - CP\% - EE \% - Ash\%) against estimates of sugar and starch by enzymatic methods, and found over-estimation when starch was below $50 \%$ of NSC. They derived a correction equation:

$$
\mathrm{NSC} \%(\text { actual })=1.249 \mathrm{NSC} \%(\text { calculated })-16.97
$$

This correction equation emphasises the inadequate definition in the model of the components of NSC, i.e. sugars, starches, pectins and organic acids.

Pitt et al. (1996) state that limiting the degradation rate for the A and $\mathrm{Bl}$ CHO fractions to $13 \%$ /h only had minor effects (see Figure 1 earlier) upon the predicted VFA proportions, but no statement is made about the amounts of VFA produced. The proportions of the VFA produced were also poorly predicted, but others (e.g. Neal et al., 1992) have encountered the same problem. This may be due to reliance on the stoichoimetric relationships of Murphy et al. (1982) and Murphy (1984). Pitt et al. (1996) also concluded that the CNCPS model was using estimated ruminal B1 degradation rates substantially greater than actual degradation rates. Gas production in vitro estimates of nutrient degradation rates (Schofield and Pell, 1995) also suggest lower rates of fermentation for the A and Bl fractions of carbohydrate than adopted in the model. However, lowering the B1 fraction degradation rate significantly would lower predicted NSC microbial synthesis in the CNCPS model.

\section{Prediction of methane production}

The original series of papers and the current software version of the CNCPS model do not predict methane or carbon dioxide outputs from the rumen, although methane losses are included (plus urine losses) in the calculation of diet ME values from DE value. After total digested organic matter (or in this case TDN) has been calculated, TDN is converted to DE by using $4.4 \mathrm{kcal} / \mathrm{g}$ TDN, and then to ME by applying a $\mathrm{DE} / \mathrm{ME}$ coefficient of 0.82 to allow for losses of both methane and urine. Pitt et al. (1996) have published a first attempt at including such a submodel. The stoichiometric procedure of Wolin (1960) was used, based on the cal- 
culated production of propionate from the microbial degradation of $\mathrm{A}, \mathrm{B} 1$ and $\mathrm{B} 2$ $\mathrm{CHO}$ fractions. This was then adjusted for rumen $\mathrm{pH}$ value, on the basis that at $\mathrm{pH}$ 6.0 , methane production was found to be nil by Strobel and Russell (1986). Calculated methane production was within $\pm 15 \%$ of the levels measured by the latter workers at a rumen $\mathrm{pH}$ of 6.7 . The amounts of propionate were calculated using the empirical stoichiometric relationships of Murphy et al. (1982) and Murphy (1984) commented on in the discussion of prediction of VFA production above.

\section{ACKNOWLEDGEMENTS}

The author gratefully acknowledges much valuable help and criticism of this manuscript from a number of people during its preparation, and also the supply of relevant reprints and manuscripts of papers in press. Dr D.G. Fox of Cornell University supplied an open version of the then (1997) current CNCPS computer model, whilst Dr W. Chalupa of Pennsylvania University supplied an equation listing for CPM Dairy and additional comments. Dr J. Dijkstra of Wageningen University contributed comments on the mathematical modelling aspects of the CNCPS. Funding for this work was provided by the M $\triangle$ FF LINK Project Feed into Milk, which is gratefully acknowledged.

\section{REFERENCES}

AFRC, 1992. Nutritive Requirements of Ruminant Animals: Protein. Technical Committee on Responses to Nutrients, Report No. 9. Nutr. Abs. Rev. Ser. B 62, 787-835

AFRC, 1993. Energy and Protein Requirements of Ruminants. CAB International, Wallingford (UK) ARC, 1980. The Nutrient Requirements of Ruminant Livestock. Technical Revicw by an Agricultural Research Council Working Party. Commonwealth Agricultural Bureau, Farnham Royal (UK)

ARC, 1984. The Nutrient Requirements of Ruminant Livestock, Supplement No.1. Report of the Protein Group of the ARC Working Party. Commonwealth Agricultural Bureau, Farnham Royal (UK)

Baldwin R.L., Koong J.J., Ulyat M.J., 1977. A dynamic model of ruminant digestion for evaluation of factors affecting nutritive valuc. Agr. Syst. 2, 255-288

Bauchart D., Legay-Carnier F., Doreau M., Gaillard B., 1990. Lipid metabolism of liquid associated and solid adherent bacteria in rumen contents of dairy cows offered lipid-supplemented diets. Brit. J. Nutr. 63, 563-578

Clark J.H., Klusmeyer 'T.H., Cameron M.R., 1992. Microbial protein synthesis and flows of nitrogen fractions to the duodenum of dairy cows. J. Dairy Sci. 75, 2304-2323

Czerkawski J.W., 1976. Chemical composition of microbial matter in the rumen. J. Sci. Food Agr. $27,621-632$

Dijkstra J., 1994. Simulation of the dynamics of protozoa in the rumen. Brit. J. Nutr. 72, 679-699 
Dijkstra J., France J., 1996. A comparative evaluation of models of whole rumen function. Ann. Zootech. 45, Suppl., 175-192

Dijkstra J., Neal H.D.StC., Beever D.E., France J., 1992. Simulation of nutrient digestion, absorption and outflow in the rumen: model description. J. Nutr. 64, 2239-2256

Dijkstra J., Boer H., van Bruchem J., Bruining M., Tamminga S., 1993. Absorption of volatile fatty acids from the rumen of lactating dairy cows as influenced by volatile fatty acid concentration, $\mathrm{pH}$ and rumen liquid volume. Brit. J. Nutr. 69, 385-396

Dijkstra J., France J., Tamminga S., 1997. Integration of in vivo parameters by mechanistic modelling to predict recycling of microbial nitrogen in the rumen. In: In Vitro Techniques for Measuring Nutrient Supply to Ruminants, BSAS Occasional Publication No. 22, pp. 158-160

Faichney G.J., White G.A., 1983. Methods for the Analysis of Feeds Eaten by Ruminants. CSIRO, Blacktown NSW (Australia)

Fox D.G., Sniffen C.J., O'Connor J.D., Russell J.B., Van Soest P.J., 1990. The Cornell Net Carbohydrate and Protein System for Evaluating Cattle Diets. Comell University Agricultura! Experimental Station, Ithaca NY (USA)

France J., Thomley J.H.M., Beever D.E., 1982. A mathematical model of the rumen. J. Agr. Sci. 99, 343-353

Goering H.K., Van Soest P.J., 1970. Forage Fiber Analysis, Agriculture Handbook No. 379. Agricultural Research Service, USDA, Washington DC (USA)

INRA, 1988. Alimentation Des Bovins, Ovins et Caprins. R. Jarrige (Editor). INRA, Paris (France)

Lopez S., France J., Dhanoa M.S., 1994. A correction for particulate matter loss when applying the polyester bag method. Brit. J. Nutr. 71, 135-137

Madsen J., 1985. The basis for the proposed Nordic protein evaluation system for ruminants. The AAT- PBV system. Acta Agr. Scand., Suppl. 25, 9-20

Mertens D.R., 1985. Effect of fiber on feed quality for dairy cows. $48^{\text {th }}$ Minnesota Nutrition Conference, St Paul MN (USA), p. 209

Mertens D.R., 1997. Creating a system for meeting the fiber requirements of dairy cows. J. Dairy Sci. $80,1463-148 i$

Murphy M.R., Baldwin R.L., Koong L.J., 1982. Estimation of stoichiometric parameters for rumen fermentation of roughage and concentrate diets. J. Anim. Sci. 55, 41!-421

Murphy M.R., 1984. Modelling production of volatile fatty acids in ruminants. In: R.L. Baldwin, A.S. Bywater (Editors). Modelling Ruminant Digestion and Metabolism. Proceedings of $2^{\text {nd }}$ International Workshop, Davis CA (USA), pp. 59-62

Neal H.D.StC., Dijkstra J., Gill M., 1992. Simulation of nutrient digestion, absorption and outflow in the rumen: model evaluation. J. Nutr. 122, 2257-2272

NRC, 1985. Ruminant Nitrogen Usage. National Academy of Science, Washington DC (USA)

NRC, 1988. Nutrient Requirements of Dairy Cattle. $6^{\text {th }}$ Edition. National Academy of Science, Washington, DC (USA)

NRC, 1996. The Nutrient Requirements of Beef Cattle. $7^{\text {th }}$ Edition. National Academy of Science, Washington DC (USA)

Oldham J.D, 1984. Protein-energy interrelationships in dairy cows. J. Dairy Sci. 67, 1090-1114

Ørskov E.R., Mehrez A.Z., 1977. Estimation of extent of protein degradation from basal feeds in the rumen of sheep. Proc. Nutr. Soc. 36, 78A

Pirt S.J., 1965. The maintenance energy of bacteria in growing cultures. Proc. Roy Soc. London, Ser. B 163, 224-231

Pitt R.E., Pel! A.N., Fox D.G., Cross L.T., Barry M.C., 1995. Remodelling the Cornell model. Proceedings of Cornell Nutrition Conference, Ithaca NY (USA), pp. 142-149 
Pitt R.E., Van Kessel J.S., Fox D.G., Pell A.N., Barry M.C., Van Soest P.J., 1996. Prediction of ruminal fatty acids and $\mathrm{pH}$ within the net carbohydrate and protein system. J. Anim. Sci, 74, 226-244

Purser D.B., Buechler S.M., 1966. Amino acid composition of rumen organisms. J. Dairy Sci. 49, 81-84

Russell J.B., Sniffen C.J., 1984. Effect of carbon-4 and carbon-5 volatile fatty acids on growth of mixed rumen bacteria in vitro. J. Dairy. Sci. 67, 987-994

Russell J.B., O'Connor J.D., Fox D.G., Van Soest P.J., Sniffen C.J., 1992. A net carbohydrate and protein system for evaluating cattle diets: I Ruminant fermentation. J. Anim. Sci. 70, 3551-3561

SCA, 1990. Feeding Standards for Australian Livestock. CSIRO, Melbourne (Australia)

Schofield P., Pe!l A.N., 1995. Validity of using gas pressure readings to measure forage digestion in vitro: a comparison involving three forages. J. Dairy Sci. 78, 2230-2238

Sniffen C.J., O'Connor J.D., Van Soest P.J., Fox D.G., Russell J.B., 1992. A net carbohydrate and protein system for evaluating cattle diets: II Carbohydrate and protein availability. J. Anim. Sci. $70,3562-3577$

Storm E., Ørskov E.R., 1983. The nutritive value of rumen micro-organisms in ruminants. Largescale isolation and chemical composition of rumen micro-organisms. Brit. J. Nutr. 50, 463-470

Strobel H.J., Russell J.B., 1986. The effect of pl I and energy spilling on bacterial protein synthesis by carbohydrate limited cultures of mixed rumen bacteria. J. Dairy Sci. 69, 2941-2947

Tamminga S., Van Straalen W.M., Subnel A.P.J., Meijer R.G.M., Steg A., Wever C.J.G., Blok M.C., 1994. The Dutch protein evaluation system: the DVE/OEB system. Livest. Prod. Sci. 40, 139-155

Wolin M.J., 1960. A theoretical rumen fermentation balance. J. Dairy Sci. 43, 1452-1459

\section{STRESZCZENIE}

\section{Krytyka „Cornell Net Carbohydrate and Protein System” ze szczególnym odniesieniem do bydta mlecznego. 1. Model żwacza}

Cornell Net Carbohydrate and Protein System (CNCPS) jest przede wszystkim modelem określającym podaż składników pokarmowych, ponieważ nie uwzględnia wykorzystania wchłoniętych składników pokarmowych i różni się od systemów energii netto NRC (1988) i bialka dostępnego NRC (1985) do obliczania zapotrzebowania zwierząt na energię, białko i aminokwasy (AA). Model CNCPS uwzględnia czynnikj dotyczące przemian żwaczowych, których nic uwzględniają inne opublikowane modele określające zapotrzebowania na energię i białko, zwłaszcza tempo rozkładu węglowodanów, przewidywanego pH oraz bilansu azotu i peptydów w żwaczu. Model nie określa proporcji lotnych kwasów tłuszczowych (VFA) ani produkcji metanu. Zakłada on, że rozwój mikroorganizmów zależy od tempa rozkładu węglowodanów, podezas gỏy inne modele matematyczne odnoszą wzrost masy bakteryjnej w żwaczu do stężenia składników pokarmowych w płynnej treści żwacza i wymagają określenia objętości źwacza i masy drobnoustrojów. Wydajność produkcji drobnoustrojów rozkładających strukturalne węglowodany (SC) nie jest ograniczona lub uzależniona od ilości dostępnego w żwaczu anoniaku, w wyniku czcgo obliczenia stechiometryczne moga prowadzić do otrzymania niepewnych ilości białka drobnoustrojów i ujemnego poziomu amoniaku w żwa- 
czu. Tylko określona ilość dostarczanych peptydów modylikuje wzrost bakterii rozkładających niestrukturalne węglowodany (NSC). Przyjęte tempo przepływu cząstek stałych jest niskie przy wysokim poziomic żywicnia w porównaniu z ARC (1984) i AFRC (1992), w wyniku czego oszacowany udział masy organicznej strawionej w żwaczu jest większy (około 0,75) niź średnie wartości 0,65 przyjęte przez ARC (1980). Model ten nie uwzględnia wplywu tempa przepływu płynnej treści żwacza na wypływ NPN, AA i rozpuszczalnego białka, pcktyn, cukrów, kwasów organicznych i VFA. W tym modelu przyjęto, że jedynie peptydy zależą od wypływu płynnej treści ze żwacza. Proponowana szybkość rozkładu węglowodanów frakcji A i Bl jest bardzo duża, przewyższająca możliwe tempo wzrostu drobnoustrojów, a więc synteza mikroorganizmów nie odpowiada znacznej zınienności przy takim wysokim tempie rozkładu. Przyjęta maksymalna wartość wydajności produkcji mikroorganizmów z węglowodanów strukturalnych i niestrukturalnych obniża wartość produkcji bakterii żwaczowych o $20 \%$ na potrzeby wzrostu pierwotniaków, jednakże pierwotniaki nie sa wliczane do puli wypływającego azotu AA mikroorganizmów. Do wartości ubytku skrobi w żwaczu nie wprowadzono poprawek na ijość skrobi pobicranej przez pierwotniaki i jej ponowne pojawienie się w jelicie; nie uwzględniono też udziału pierwotniaków w przemianach tłuszczu w żwaczu. Przewidywana wartość TDN dla pasz zielonych jest powiązana głównie $z$ tempem rozkładu ścian komórkowych roślin. Tylko jeden czynnik dotyczący diety, efektywny rozkład neutralnego włókna detergentowego (eNDF\%), definniuje bądź modytikuje maksymalną produkcję mikroorganizmów i ich utrzymanie, rzeczywistą wydajność mikroorganizmów i tempo rozkładu SC i NSC. Konsekwencją tego jest to, że na ilość dostarczonej krowie energii i białka wpływa parametr eNDF, kiedy zawartość suchej masy w diecie wynosi poniżej $25 \%$. 